Original Research Paper

\title{
Pola Prilaku Keberadaan Semut Famili Formicidae pada Tepian Sungai Musi Gandus Kota Palembang Sumatera Selatan
}

\author{
Ari Saputra ${ }^{1}$, Zainal Arifin ${ }^{1}$, Riyanto $^{1 *}$ \\ ${ }^{1}$ Program Studi Pendidikan Biologi FKIP Universitas Sriwijaya, Indonesia;
}

\section{Riwayat artikel}

Received : 02 Maret 2020

Revised : 22 Maret 2020

Accepted : 07 April 2020

Published : 16 April 2020

*Corresponding Author:

Riyanto,

Program Studi Pendidikan Biologi FKIP Universitas

Sriwijaya, Indonesia;

Email: riyanto@ fkip.unsri.ac.id
Abstrak: Faktor alam dan lingkungan dapat mempengaruhi pola keberadaan semut. Penelitian ini bertujuan untuk mempelajari pola keberadaan semut tanah di area permukiman tepian Sungai Musi Kecamatan Gandus Palembang. Metode penelitian ini adalah deskriftif.Stasiun penelitian meliputi rumah, tepi sungai, semak, butan dan kebun. Pengambilan contoh sampel semut menggunakan metode hand collecting dan perangkap umpan (baited trap).Hasil penelitian semut tanah Solenopsis germinata dan Paratrechina longicornis hampir ditemukan disemua stasiun.Spesies semut yang paling sedikit ditemukan, yaitu Diacamma intricatum danPheidole megacephala. Rumah kurang dari $100 \mathrm{~m}$ dari tepi sungai Musi ditemukan tiga spesies semut, yaitu dua dari subsuku Myrmicinae dan satu dari Formicinae ( $S$. germinata, $P$. megacephala dan $P$. longicornis). Ketiga spesies ini sama dengan yang ditemakan pada semak-semak. Lokasi yang berjarak 100-200 m dari tepi sungai memiliki komposisi dan keanekaragaman semut yang semakin meningkat. Stasiun rumah ditemukan sebanyak tiga spesies, yaitu $S$. germinata, Pheidole sp, dan P. longicornis. Stasiun semakditemukantiga jenis semut, yaitu S. Germinate, Monomorium pharaonisdan T. melanocephalum. Stasiun kebun ditemukan empat spesies, yaitu: Acanthomyrmex sp., $S$. germinata, $P$. longicornis, danCamponotus ligniperda.Stasiun hutan ditemukan enam spesies yaitu: Acanthomyrmex sp., S. germinata, P.longicornis, Camponotus ligniperda danDiacamma intricatum. Jumlah jenis semut yang paling banyak ditemukan adalah di stasiun hutan. Pola keberadaan semut di berbagai lokasi tepian sungai Musi Gandus Palembang memiliki pola fluktuasi jumlah dan jenisnya.

Kata kunci: semut tanah, pola keberadaan, sungai Musi danPalembang

Abstract: The natural and environmental factors can affect the pattern of ants. This study aims to study the pattern of the presence of soil ants in the settlement area of the banks of the Musi River, Gandus, Palembang. This research method is descriptive. The research station includes houses, river banks, bushes, butane and gardens. The sampling ant samples using the method of hand collecting and baited traps. The results of research on the ground ants Solenopsis germinata and Paratrechina longicornis are found in almost all of stations. The fewest ant species found were Diacamma intricatum and Pheidole megacephala. The houses less than $100 \mathrm{~m}$ from the banks of the Musi river are found by three ant species, namely two from the Myrmicinae sub-tribe and one from Formicinae ( $S$. germinata, $P$. megacephala and $P$. longicornis). These three species are the same as those found in bushes. The location which is 100-200 $\mathrm{m}$ from the river bank has an ant composition and diversity that is increasing. The housestations were found as many as three species, namely $S$. germinata, Pheidole $s p$, and $P$. longicornis. The bush station found three types of ants, namely $S$. Germinate, Monomorium pharaonis and T. melanocephalum. The garden station found four species, namely: Acanthomyrmex sp., S. germinata, P. longicornis, and Camponotus ligniperda. The forest station found six species, namely: 
Acanthomyrmex sp., S. germinata, P.longicornis, Camponotus ligniperda and Diacamma intricatum. The number of ant species most commonly found is at the forest station. It can be concluded that the pattern of the presence of ants in various locations on the banks of the Palembang Gandus Musi river has a fluctuation in the number and type.

Keywords: soil ants, existance pattern, Musi river, Palembang

\section{Pendahuluan}

Hubungan semut dengan manusia telah diketahui sejak jaman nabi Sulaiman AS, hal ini seperti yang dikisahkan dimana Nabi Sulaiman AS dan pasukannya tiba di suatu lembah. Selanjutnya di lembah tersebut disaksikan banyak sarang semut dan saat itu banyak sekali pasukan nabi Sulaiman AS, maka salah satu raja semut memerintahkan hai semut-semut, masuklah ke dalam sarang-sarangmu agar kamu tidak diinjak oleh Sulaiman dan tentaranya, sedangkan mereka tidak menyadari" (QS an-Naml: 18). Manusia tidak sadar, jika melihat di sekeliling sangat mudah menemukan semut. Kebiasaan kita sering membuat sampah organik, menanam pohon, dan menumpuk barang justru dapat menarik semut, sebab semut dapat menemukan sumber makan, membuat sarang dan perlindungan. Beberapa jenis semut mampu beradaptasi dengan baik di lokasi habitat yang terganggu. Kehadiran manusia dapat mengganggu keanekaragaman semut. Semut dapat berasosiasi dengan manusia dan manusia bukan menjadi faktor penghambat bagi semut untuk tetap hidup. Semut yang memilki berperilaku ini disebut dengan semut tramp (Hasriyanty et al.2013).

Faktor alam dan faktor manusia dapat mempengaruhi keberadaan semut. Menurut Latumahina (2015) semut dapat mengalami dampak negatif yang diakibatkan degradasi dan fragmentasi habitat. Pada kondisi ini kelimpahan, kekayaan dan frekuensi semut mengalami fluktuasi dalam habitatnya. Semut mempunyai peran yang sangat penting di hutan sekunder. Oleh sebab itu, keberadaan semut harus tetap dipelihara sebagai bagian dari komponen pendukung ekosistem. Aktivitas manusia perlu dibatasi di kawasan hutan sekunder yang berguna untuk menjaga kelangsungan hidup komunitas semut serta komponen pendukung ekosistem lainnya. Philpott dan Armbrecht (2006) melaporkan bahwa praktik pertanian intensif dapat mendorong hilangnya keanekaragaman hayati. Untuk tujuan konservasi dan produksi, praktik pertanian harus kompatibel dengan keanekaragaman hayati, sebagai contoh pohon peneduh pada perkebunan kopi dan coklat dapat menyediakan perlindungan bagi keanekaragaman hayati dan juga dapat meningkatkan fungsi ekosistem tertentu misalnya prédator. Keberadaan semut erat kaitannya dengan kondisi habitat seperti suhu (Andersen, 2000). Suhu yang sangat rendah menyebabkan aktivitas metabolisme semut terganggu bahkan dapat menyebabkan kematian. Oleh karena itu, semut sulit ditemukan di wilayah kutub (Campbellet al., 2018).

Semut memiliki peran penting pada ekosistem. Philpott dan Armbrecht (2006) melaporkan semut merupakan kelompok predator penting dalam ekosistem tropis. Namun, keanekaragaman hayati semut dapat menurun dengan intensifikasi kopi dan kakao. Hilangnya keanekaragaman ini mempengaruhi peran semut sebagai predator Phillpot et al. (2009) menyatakan kemampuan pengendalian hayati semut akan menurun seiring dengan terjadinya gangguan habitat seperti hilangnya keragaman dan perubahan struktur vegetasi. Sebagai salah satu penyusun ekosistem tentu semut turut mengalami gangguan (Latumahina etal. 2015). Semut berperan sebagai predator hama dan pakan burung. Peran semut sebagai predator, yaitu pengendalian populasi hama (Yudiyantoet al., 2014) misalnya semut rangrang. Semut rangrang dapat memakan telur, larva, pupa dan imago serangga hama.Semut dapat "merekayasa" ekosistem misalnya mengaerasi tanah, sehingga sirkulasi nutrien menjadi lebih baik. Pada sisi lain, semut berperan merugikan. Semut dapat menginvasi lalu menyerang dan mendominasi habitat tropis, sehingga semut dapat mengancam fauna dan flora lokal. Walker (2006) menyatakan semut Wasmania punctata secara drastis dapat menurunkan keanekaragaman semut dengan cara invasif serta mudah menyebar dan pada akhirnya berujung pada kepunahan spesies lain. Peran semut dalam ekosistem juga terlihat di Tepian sungai Musi Gandus Palembang.

Shidqi (2015) menemukan 4 subfamili, 7 genus dan 14 spesies di desa Parang Teritis Yogyakarta. Penemuan ini sebagai bukti bahwa semut bisa hidup dan berkembangbiak pada pemukiman pendududk. Penelitian yang terkait semut dan serangga lainnya telah dilakukan Riyanto \& Tibrani (2016). Hasil penelitiannya menemukan 204 spesies serangga yang termasuk pada 70 famili, dan 10 ordo di daerah aliran Sungai Musi Palembang pada 4 lokasi yang berbeda. Namun, penelitian tersebut mencakup data spesies apa saja yang terdapat di tepian sungai Musi kota Palembang, bukan fokus pada serangga semut dan pola keberadaan semut. Oleh karena itu, dilakukan penelitian pola keberadaan semut tanah di tepian sungai Musi Gandus Palembang. Hal ini disebabkan oleh jumlah 
individusemut yang berlimpah serta peran semut yang krusial dalam ekosistem. Gandus adalah daerah yang terletak di tepian sungai Musi Palembang. Pada saat ini Gandus masih memiliki hutan dan perkebunan. Namun karena aktivitas manusia, wilayah ini berangsur-angsur mengalami perubahan faktor biotik dan abiotik yang sangat memengaruhi pola keberdaan semut tanah dan fungsi lingkungan. Penelitian ini bertujuan untuk mempelajari pola keberadaan semut tanah di area permukiman tepian sungai Musi kecamatan Gandus Palembang.

\section{Bahan dan Metode}

\section{Tempat dan Waktu}

Tempat penelitian di tepian Sungai Musi Gandus Kota Palembang. Identifikasi sampel semut dilaksanakan di laboratorium Pendidikan Biologi FKIP Unsri. Lokasi pengambilan sampel semut meliputi: tepi sungai Musi, rumah, kebun, hutan dan semak dengan jarak <100 m dari badan sungai Musi, serta habitat rumah, semak, kebun, dan hutan yang berjarak 100-200 m dari badan sungai Musi.

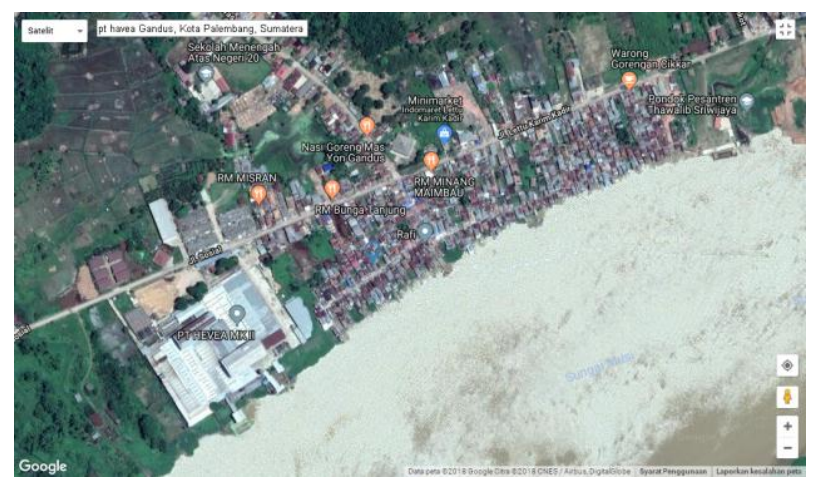

Gambar 1. Peta Lokasi Penelitian

(Sumber: Google map yang diakses tanggal $28 \mathrm{Mei}$ 2018)

Jarak dari tepian sungai Musi adalah wilayah darat 5 meter dari perairan sungai Musi.Tepian sungai Musi merupakan titik awal tempat pengambilan sampel ketika sungai Musi sedang surut.Tepian sungai Musi seringkali digunakan warga yang tinggal dekat sungai Musi untuk mandi (Setiawan, 2018). Penelitian ini telah dilaksanakan dari bulan Mei 2018 sampai Desember 2018.

Metode penelitian ini adalah metode deskriftif. Metode deskriptif, yaitu penelitian berdasarkan realitas dan fakta keadaan di lapangan secara apa adanya.Sampel semut diambil pada tiap-tiap perbedaan jarak dengan tepi sungai Musi. Teknik pengambilan sampel semut adalah purposive sampling.Purposive sampling adalah teknik pengambilan sampel semut dengan tujuan tertentu secara sengaja.Pertimbangan ini didasarkan tujuan apa yang ingin peneliti capai dan peneliti ingin diketahui (Palys, 2008).Tujuannya adalah sampel yang diambil dan lokasinya. Pertimbangan meliputi: 1) kondisi stasiun yang memungkinkan buat operasional sampling 2) habitatnya semut tanah 3) stasiun harus mewakili keanekaragaman spesies semut tanah. Oleh karena itu, sampel semut tanah diambil sebanyak 7 stasiun, yaitu: tepi sungai, semak, rumah, hutan dan kebun. Pengambilan sampel semut tanah digunakan metode baited trap dan hand collecting (Agosti, et al. 2000).

\section{Penentuan lokasi sampel}

Lokasi sampel ditentukan berdasarkan hasil survei, yaitu lokasi banyak terdapat semut tanah. Selanjutnya lokasi stasiun penelitian didasarkanpada kondisi habitat yang berbeda di tepian Sungai Musi. Stasiun-stasiun tersebut mewakili permukiman warga yang dibagi dengan kategori berikut ini (Tabel 1):

Tabel 1. Lokasi penelitian di tepian sungai Musi Palembang

\begin{tabular}{ccll}
\hline $\begin{array}{c}\text { Jarak } \\
\text { dari tepi } \\
\text { sungai }\end{array}$ & $\begin{array}{c}\text { Jumlah } \\
\text { Plot }\end{array}$ & Lokasi & \multicolumn{1}{c}{ Deskripsi } \\
\hline & 6 & $\begin{array}{c}\text { Tepi } \\
\text { Sungai }\end{array}$ & $\begin{array}{l}\text { Tepian sungai berupa } \\
\text { daratan tanah yang } \\
\text { terdampak pasang } \\
\text { surut. }\end{array}$ \\
\cline { 2 - 4 } & 12 & Rumah & $\begin{array}{l}\text { Dalam rumah dan } \\
\text { pekarangan }\end{array}$ \\
\cline { 2 - 4 } & 6 & Semak & $\begin{array}{l}\text { Lahan yang tidak } \\
\text { diolah untuk budidiaya }\end{array}$ \\
\cline { 2 - 4 } m & 12 & Rumah & $\begin{array}{l}\text { Dalam rumah dan } \\
\text { pekarangan }\end{array}$ \\
\cline { 2 - 4 } & 6 & Semak & $\begin{array}{l}\text { Lahan yang tidak } \\
\text { diolah untuk budidiaya }\end{array}$ \\
\cline { 2 - 4 } & 6 & Kebun & $\begin{array}{l}\text { Perkebunan tanaman } \\
\text { tebu }\end{array}$ \\
\hline Total & 54 & Hutan & $\begin{array}{l}\text { Hutan di tepi sungai } \\
\text { Musi }\end{array}$ \\
\hline
\end{tabular}

\section{Pengamatan dan pengambilan contoh sampel semut}

Contoh sampel semut diambil pada pagi dan sore hari.Kegiatan ini dilakukan dengan hati-hati, agar bagian organ tubuh semut tidak rusak. Lalu sampel semut dimasukkan ke dalam botol berisi alkohol 70\%.Sampel sampel semut iidentifikasi di laboratorium Penididikan Biologi FKIP Unsri dengan literatur Hölldobler dan Wilson (1990) dan Bolton (1994). Pengambilan sampel digunakan dua metode (Hashimoto, 2003) yaitu:

\section{Metode hand collecting}

Metode ini adalah koleksi sampel semut menggunakan tangan yang dibantu pinset dan kapas 
serta alkohol. Metode ini digunakan pada tempat area tanah yang mudah dijangkau oleh peneliti.

\section{Metode baited trap}

Metode ini dipakai pada tempat-tempat yang sulit seperti semut yang berada dalam lubang, serasah daun dan kayu-kayuan. Caranya potongan madu dan ikan tuna kaleng diletakkan di kertas. Kondisi ini diharapkan semut yang berada pada tempat yang sulit akan datang, sehingga diperoleh jenis-jenis semut tanah dan sekaligus tahu peranan semut pada habitatnya (Wielgoss et al,, 2010. dalam Hasriyanty et al.,2013). Pengambilan sampel semut dikerjakan satu jam dengan mengamati semut-semut tanah yang memakan umpan setiap 15 menit.

\section{Faktor fisik lingkungan yang diukur}

Faktor lingkungan diukur untuk mendapat informasi secara komprehensif penyebab eksistensi spesies semut tertentu. Pengukuran faktor abiotik sangat penting, sebab faktor abiotik tersebut memiliki pengaruh terhadap keberadaan dan kepadatan populasi hewan tanah (Suin, 2007). Faktor lingkungan meliputi: udara, suhu, kelembaban udara, kelembabab tanah, suhu tanah, dan $\mathrm{pH}$ tanah.

\section{Pengamatan Pola keberadaan Semut Tanah di Area Permukiman}

Pola keberadaan semut yang dimaksud, yaitu pola yang dilihat berdasarkan jumlah spesies semut yang berhasil ditemukan pada setiap habitat (Allee et al. 1967). Kondisi habitat tertentu memengaruhi keberadaan dan komposisi semut. Waktu pengamatan dari pukul 09.00-10.00 dan 15.00-17.00 WIB (Hasriyanty, 2013).

Data hasil penelitian dibuat dokumentasi, lalu sampel semut diidentifikasi sampai tingkat genus. Selanjutnya identifikasi dikerjakan di laboratoirum Pendidikan Biologi FKIP Universitas Sriwijaya. Buku identifikasi semut, yaitu Hölldobler dan Wilson (1990) dan Bolton (1994).

Pengidentifikasian diawali dengan menghitung panjang total tubuh semut, yaitu dihitung dari mandibula bagian anterior sampai abdomen bagian posterior (hipopygidium). Antena, yaitu dihitung jumlah segmennya dari scape dan funiculus. Selanjutnya dilihat ada atau tidaknya promesonotalsuture. Jika memiliki promesonotal suture, maka pronotum dan mesonotum tidak mengalami fusi. Begitupun sebaliknya, apabila tidak memiliki promesonotalsuture, maka pronotum dan mesonotum berfusi.

Lalu, dilihat bagian mesosoma yang terdiri dari pronotum, mesonotum, dan propodeum (fusi antara mesosoma dan gaster). Bagian poopodeum diamati apakah berduri atau tidak. Selanjutnya dilihat bagian petiole, dihitung jumlahnya, dan diamati bentuknya.
Lalu dihitung jumlah abdomen serta dilihat apakah memiliki senjata berupa acidopore, sengat atau tidak memiliki sama sekali. Terakhir diamati warna tubuh semut.

\section{Analisis Data}

Analisis data pola keberadaan semut digunakan analisis deskriftif. Data pola keberadaan dan jumlah semut di setiap stasiun dideskrifsikan dengan cara dibuat tabel dan gambar grafiknya (Nicholas, 2006).

\section{Hasil dan Pembahasan}

\section{Pola Keberadaan Semut Tanah di Tepian Sungai Musi Gandus Kota Palembang}

Pola keberadaan semut tanah ditepian sungai Musi Gandus Palembang bervariasi. Peneliti melaporkan keberadaaan semut dari berbagai stasiun yang ada di tepian sungai Musi Gandus Palembang. Untuk lebih jelas dapat dilihat pada Tabel 2.

Tabel 2. Keberadaan semut tanah pada berbagai stasiun di Tepian Sungai Musi Kota Palembang

\begin{tabular}{|l|l|c|c|c|c|c|c|c|c|}
\hline \multirow{2}{*}{ No } & \multirow{2}{*}{ Spesies } & \multicolumn{7}{|c|}{ Jarak } \\
\cline { 3 - 9 } & & \multicolumn{2}{|c|}{ Jarak<100 $\mathrm{m}$} & \multicolumn{3}{l|}{$\mathrm{m}$} \\
\cline { 2 - 9 } 1. & $\begin{array}{l}\text { Acanthomyrmex } \\
\text { sp. }\end{array}$ & - & - & - & - & - & - & + & + \\
\hline 2. & $\begin{array}{l}\text { Solenopsis } \\
\text { germinata }\end{array}$ & - & + & + & - & + & + & + & + \\
\hline 3. & $\begin{array}{l}\text { Monomorium } \\
\text { pharaonis }\end{array}$ & - & - & - & - & - & + & - & - \\
\hline 4. & $\begin{array}{l}\text { Pheidole } \\
\text { megacephala }\end{array}$ & + & + & + & - & + & - & - & - \\
\hline 5. & $\begin{array}{l}\text { Paratrechina } \\
\text { longicornis }\end{array}$ & - & + & + & - & + & - & + & + \\
\hline 6. & $\begin{array}{l}\text { Tapinoma } \\
\text { melanocephalum }\end{array}$ & - & - & - & - & - & + & - & + \\
\hline 7. & $\begin{array}{l}\text { Camponotus } \\
\text { ligniperda }\end{array}$ & - & - & - & - & - & - & + & + \\
\hline 8. & $\begin{array}{l}\text { Diacamma } \\
\text { intricatum }\end{array}$ & - & - & - & - & - & - & - & + \\
\hline & Total & 1 & 3 & 3 & 0 & 3 & 3 & 4 & 6 \\
\hline
\end{tabular}

Keterangan: TS (tepi sungai), Rmh (rumah), Smk (semak), Htn (kebun) dan Kbn (kebun). - (tidak ditemukan semut) dan + (ditemukan semut).

Secara metode dan jumlah plot yang digunakan pada penelitian ini telah sesuai untuk mengoleksi sebagian besar semut tanah pada setiap stasiun. Spesies semut tanah Solenopsis germinata dan Paratrechina longicornis hampir ditemukan disemua stasiun.Kedua spesies ini hadir di lokasi permukiman, kebun, semaksemak dan hutan dengan jarak 100 m serta pada jarak 100-200 m. Spesies yang paling sedikit ditemukan, yaitu Diacamma intricatum kehadirannya hanya ditemukan di 
hutan serta Pheidole megacephala hanya ditemukan di tepi sungai Musi saja. Stasiun tepi sungai Musi hanya didominasi oleh jenis semut tersebut yang mendatangi setiap umpan. Rumah kurang dari 100 m dari tepi sungai Musi ditemukan tiga spesies semut tanah, yaitu dua dari subsuku Myrmicinae dan satu dari Formicinae ( $S$. germinata, P. megacephala dan P. longicornis). Ketiga spesies ini sama dengan yang ditemakan pada semaksemak.

Lokasi yang berjarak 100-200 m dari tepi sungai memiliki komposisi dan keanekaragaman semut yang semakin meningkat. Stasiun rumah ditemukan sebanyak tiga spesies, meliputi: $S$. germinata, $P$. megacephaladan $P$. longicornis. Stasiun berikutnya, yaitu semakditemukantiga jenis semut tetapi jenisnya berbeda dengan jenis stasiun rumah sungai. Di kebun ditemukanempat spesies, yaitu: Acanthomyrmex sp., $S$. germinata, $P$. longicornis, danCamponotus ligniperda.Stasiun hutan ditemukan enam spesies yaitu: Acanthomyrmex sp., $S$. germinata, $P$. longicornis, $C$. ligniperda danD.intricatum. Terakhir, jenis semut yang paling banyak ditemukan jumlah jenisnya adalah lokasi hutan.

\section{Faktor Fisik dan Kimia Lingkungan}

Penngukuran faktor fisik dan kimia lingkungan bertujuan untuk membuktikan bahwa faktor lingkungan yang meliputi kelembaban tanah, suhu tanah, pH tanah, suhu udara, dan kelembaban udara mempengaruhi keberadaan semut tanah. Faktor lingkungan penting untuk diukur, sebab semut sensitif dengan terjadinya perubahan lingkungan. Selama proses pengambilan sampel semut sedang terjadi peralihan antara musim kemarau ke musim penghujan. Hal ini berpengaruh terhadap keadaan suhu tanah, kelembaban tanah, $\mathrm{pH}$ tanah, suhu udara, dan kelembaban udara. Berikut faktor lingkungan yang ditabulasi dalam Tabel 3 .

Tabel 3. Faktor lingkungan yang diperoleh dari berbagai stasiun di tepian Sungai Musi

\begin{tabular}{|c|c|c|c|c|c|c|}
\hline \multirow{2}{*}{$\begin{array}{c}\text { Jarak } \\
\text { dari tepi } \\
\text { sungai } \\
\text { Musi }\end{array}$} & & \multicolumn{3}{|c|}{ Tanah } & \multicolumn{2}{|c|}{ Udara } \\
\hline & & $\mathrm{pH}$ & $\begin{array}{l}\text { Suhu } \\
\left({ }^{\circ} \mathrm{C}\right)\end{array}$ & $\begin{array}{l}\text { Kel } \\
(\%)\end{array}$ & $\begin{array}{l}\text { Suhu } \\
\left({ }^{\circ} \mathrm{C}\right)\end{array}$ & $\begin{array}{l}\text { Kel( } \\
\%)\end{array}$ \\
\hline \multirow[t]{4}{*}{$<100 \mathrm{~m}$} & $\begin{array}{c}\text { Tepi } \\
\text { sungai }\end{array}$ & 6,8 & 32 & 70 & 28 & 70 \\
\hline & Rumah & 6 & 32 & 80 & 31 & 77 \\
\hline & $\begin{array}{c}\text { Semak- } \\
\text { semak }\end{array}$ & 4,6 & 35 & 30 & 26 & 64 \\
\hline & Rumah & 6,2 & 31 & 40 & 35 & 63 \\
\hline \multirow[t]{4}{*}{$\begin{array}{l}100 \mathrm{~m} \mathrm{-} \\
200 \mathrm{~m}\end{array}$} & $\begin{array}{c}\text { Semak- } \\
\text { semak }\end{array}$ & 5,6 & 33 & 80 & 27 & 58 \\
\hline & Kebun & 5,8 & 32 & 60 & 27 & 64 \\
\hline & Hutan & 6,7 & 35 & 60 & 25 & 63 \\
\hline & $\begin{array}{c}\text { Tepi } \\
\text { sungai }\end{array}$ & 6,8 & 32 & 70 & 28 & 70 \\
\hline
\end{tabular}

Rata-rata suhu udara dan tanah di seluruh stasiun berkisar antara $26^{\circ} \mathrm{C}-31^{\circ} \mathrm{C}$ dan $31^{\circ} \mathrm{C}-35^{\circ} \mathrm{C}$. Kisaran kelemban udara berkisar antara 58\%-77\%. Nilai pH berkisar 4,6-6,8. Kelembababan tanah berkisar antara $2 \%$ - 80\%. Terdapat sedikit perbedaan pada kondisi lingkungan. $\mathrm{pH}$ tanah terendah di semak-semak $(<100$ m) dan tertinggi di tepi sungai Musi. Suhu tanah terendah ada di rumah (100-200 m), yaitu $31^{\circ} \mathrm{C}$ dan tertinggi di semak dengan suhu tanah $35^{\circ} \mathrm{C}$. Kelembaban tanah terendah ada di hutan, yaitu $2 \%$ dan tertinggi di rumah $(<100 \mathrm{~m})$ dan semak-semak $(100-200 \mathrm{~m})$, yaitu 80 $\%$. Suhu udara terendah ada di hutan dan tertinggi di semak-semak $(<100 \mathrm{~m})$ serta semak-semak $(<100 \mathrm{~m})$ dan kebun (100-200 m).

\section{Pola Keberadaan Semut Tanah di Tepian Sungai Musi Gandus Kota Palembang}

Berdasarkan jumlah spesies yang ditemukan di setiap stasiun, menunjukkan bahwa lokasi lingkungan dalam kondisi tertentu dapat berpengaruh terhadap keberadaan semut. Jumlah spesies semut yang didapatkan cenderung meningkat seiring dengan berkurangnya aktivitas manusia (Gambar 2). Stasiun yang paling tinggi keanekaragaman semut tanah adalah hutan dan yang paling rendah berada di tepi Sungai Musi.Pernyataan ini didukung oleh Latumahina et al. (2015) bahwa keberadaan dan jumlah individu semut dipengaruhi oleh penggunaan lahan. Artinya semakin tinggi gangguan manusia, maka semakin rendah keanekaragaman semut, namun jumlah spesies semut cenderung meningkat seiring dengan penurunan tingkat gangguan. Secara berturut-turut mulai dari tepi sungai, rumah, semak, kebun, dan hutan (Gambar 2 dan Tabel 3).

Setiap stasiun memiliki keanekaragaman fauna dan flora yang berbeda. Tepi sungai, didominasi oleh tumbuhan talas bogor. Stasiun kebun ditemukan tanaman pisang, tebu, cabai rawit, singkong, dan pepaya. Berdasarkan gambar 2 terjadi kenaikan jumlah spesies semut di berbagai stasiun. Penggunaan lahan untuk berbagai kebutuhan manusia mempengaruhi ketersediaan pakan dan iklim mikro di tiap tipe stasiun. Stasiun tepian sungai Musi Gandus merupakan wilayah yang dijadikan masyarakat untuk bertempat tinggal, industri karet, pertanian, dan perkebunan. Keadaan ini menyebabkan tidak semua semut dapat berkembangbiak. Semut dengan kemampuan adaptasi yang tinggi mampu hidup di lokasi ini. Hal ini didukung oleh Rizali et al. (2008), urbanisasi di area Bogor menyebabkan homogenisasi komunitas semut. Setiap stasiun memiliki jenis dan keanekaragaman semut yang berbeda-beda, sesuai dengan stasiunnya masing-masing. Satu spesies didapatkan pada tepi sungai, yaitu spesies $P$. megacephala. Stasiun yang paling banyak ditemukan jumlah spesies adalah hutan dengan 6 spesies. Penjelasan 
tentang jenis semut berdasarkan lokasi pengambilan sampel dapat di lihat pada gambar 2 .

Berikut jumlah spesies semut yang ditemukan di berbagai habitat dinyatakan dalam grafik batang (Gambar 2).

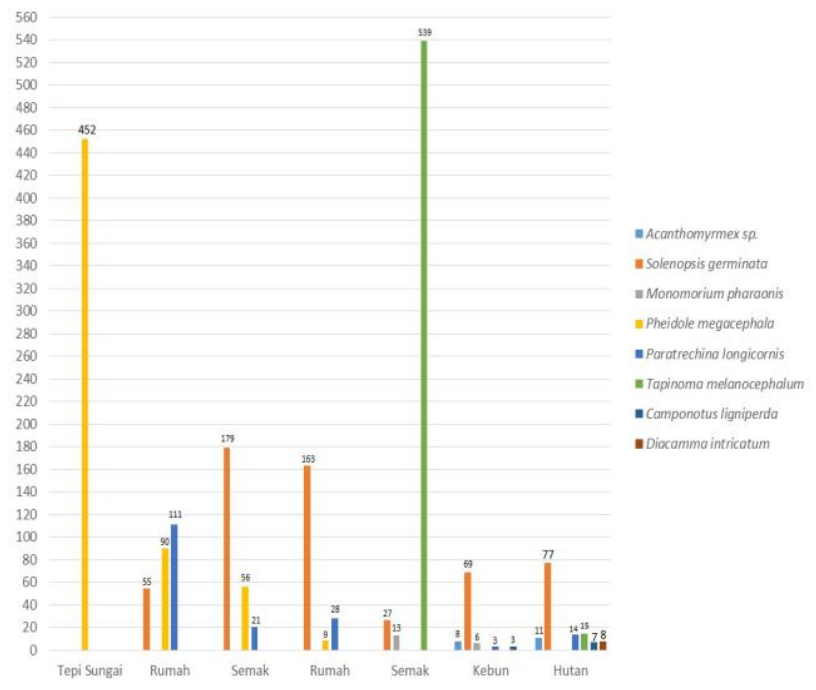

Jarak $<100$ m Jarak 100-200 m

Gambar 2. Jumlah Spesies Semut di Berbagai Stasiun

\section{Tepian Sungai Musi}

Stasiun Tepi sungai ditemukan spesies $P$. megacephala. Sebanyak 452 individu semut hadir di tanah tepian sungai Musi. Semut yang memiliki duri di propedeum ini membentuk garis pencarian makan yang tinggi. Selain itu, P. megacephala terdiri dari semut pekerja yang dimorfik (mayor dan minor). Kedua jenis pekerja ini bekerja sama untuk menjaga makanan. Pekerja minor bertugas memegang tubuh "semut penyusup" dan menjepit kakinya, kemudian pekerja mayor langsung menyerang tubuh "semut penyusup" tersebut (Hölldobler \& Wilson, 1990).

Semut tanah yang ditemukan di tepian Sungai Musi hanya satu jenis. Hal ini disebabkan vegetasi yang sangat sedikit pada habitat ini. Tumbuhan yang ditemukan mayoritas Talas Bogor (Colocasia esculenta). Sementara itu, semut-semut jenis $D$. intricatum, Acanthomyrmexsp, C. ligniperda, T. Melanocephalum dan lain-lain membutuhkan ranting, kayu mati, atau tanah untuk bersarang, mencari makan, atau pun berlindung. Contoh semut lain yang tidak dtemukan di tepi sungai Musi adalah semut rangrang (Oecophylla smaragdina). Semut dari subsuku Formicidae ini memiliki cara hidup yang khas, yaitu dengan merajut daun-daun pohon sampai daun tersebut terlipat. Hal ini dilakukan untuk membuat sarang. Semut rangrang menyukai udara segar sehingga tidak mungkin ditemukan di dalam rumah, melainkan di atas pohon tertentu (Mele \& Cuc, 2004).

\section{Rumah (<100 m)}

Rumah didominasi oleh semut tramp, yaitu: $S$. germinata, $P$. longicornis, dan P. megacephala. Ketiga jenis semut tanah tersebut biasa berasosiasi dengan manusia dan bersifat invasif. Perilaku yang invasif inilah yang menjadi alasan kuat mengapa semut-semut ini ditemukan begitu banyak di habitat rumah (Hasriyanty et al., 2013).

\section{Semak $(<\mathbf{1 0 0} \mathbf{m})$}

Semak-semak dengan jarak $<100 \mathrm{~m}$ ditemukan semut semut invasif, yaitu: $S$. germinata, $P$. megacephala, dan $P$. longicornis. Jenis-jenis semut yang ada di stasiun ini cenderung memiliki kesamaan dengan stasiun rumah yang berjarak $<100 \mathrm{~m}$, namun komposisi spesies semut berbeda. Spesies semut cenderung sama, karena stasiun semak berada dekat dengan area permukiman. Jaraknya tidak kurang dari $20 \mathrm{~m}$. Hal ini mengakibatkan semut yang hadir pun adalah semut, semut tramp dengan jenis yang sama. S.germinata 179 individu, $P$. megacephala 56 indivdu, dan P. longicornis 21 individu.

\section{Rumah (100-200 m)}

Rumah di area ini lebih lembab (Tabel 3) dibandingkan rumah di lokasi jarak <100 m, namun, jenis semut yang ditemukan sama dengan dua stasiun sebelumnya yaitu $S$. germinata, $P$. longicornis, dan $P$. megacephala. Semut-semut yang ditemukan termasuk semut tramp dan invasif. Semut yang sudah berasosiasi dengan kehadiran manusia, sehingga di stasiun rumah didapatkan semut-semut jenis ini.

\section{Semak (100-200 m)}

Semak dengan jarak 100-200 m banyak dihuni oleh semut jenis $T$. melanocephalum. Semut ini hanya ditemukan di semak-semak dan hutan. Lokasi sebelumnya memang terdapat semak-semak, tetapi masih di area permukiman manusia. Besar kemungkinan semut ini tidak mampu bersaing dengan semut-semut lain di permukiman manusia. Hal ini disebabkan ukurannya yang terbilang kecil dibanding semut pada umumnya, yaitu berkisar $\pm 2 \mathrm{~mm}$. Ukuran yang kecil ini membuat semut ini lambat dalam bergerak. Semut ini cepat melakukan migrasi ke tempat lain, apabila kondisi lingkungan tidak menguntungkan. Eleanor (2013) melaporkan bahwa ketika kondisi di luar sarang $T$. melanocephalum berubah, seperti terjadi banjir besar atau pun ada spesies dominan lain yang hadir maka semut ini akan pergi. Semut dari subsuku Dolichoderinae ini memindahkan sarangnya tiap dua minggu sekali. Selain itu, $T$. melanocephalum tidak dilengkapi perlindungan diri seperti sengat milik semut dari 
subsuku Ponerinae dan Myrmicinae atau pun acidopore seperti milik Formicinae.

\section{Kebun}

Kebun milik warga ditanami berbagai tumbuhan seperti pisang, tebu, cabai rawit, singkong dan pepaya. Tanaman yang beraneka ragam menyebabkan jenis semut yang hadir semakin meningkat. Hal ini menyebabkan kesediaan makanan makin beragam, sehingga relung hidup semut semakin tinggi. Stasiun kebun terdapat spesies Acanthomyrmex sp., $S$. germinata, P. longicornis, T. melanocepahalum, dan $C$. ligniperda.Di stasiun kebun tidak ditemukan Monomorium pharaonis. Semut inimakan secara berkoloni dengan ukuran tubuh sangat kecil. Ukuran yang kecil dan pergerakan yang lambat menyebabkan kalah kompetisi dengan jenis semut lain. Demikian pula Diacamma tidak ditemukan. Semut ini yang memiliki sengat ini bersarang di kayu besar yang sudah mati. Sementara itu, kebun tersebun tidak terdapat potongan kayu-kayu besar sebagai tempat hidup D. intricatum.

\section{Hutan}

Stasiun hutan ditemukan enam jenis semut. Jenis semut tersebut adalah Acanthomyrmex sp., S. germinata, P. longicornis, T. melanocepahalum, D. intricatum dan C. ligniperda. Hutan mampu memberikan faktor lingkungan biotik dan abiotik yang baik bagi flora dan fauna, termasuk bagi semut. Pada stasiun ini terdapat berbagai vegetasi yang heterogen, seperti kelor, lamtoro, talas bogor, teki, dan lain-lain. Vegetasi tumbuhan mampu memengaruhi ketersediaan habitat bagi serangga permukaan tanah. Serasah di atas permukaan tanah sangat menunjang kehadiran serangga.

\section{Faktor Fisik dan Kimia Lingkungan}

Kisaran $\mathrm{pH}$ pada hutan, yaitu 4,6 sampai 7 atau cenderung netral. Kisaran ini umum untuk kebanyakan makhluk hidup termasuk semut. Keadaan netral dan relatif asam, semut dapat hidup dengan baik. Derajat keasaman atau $\mathrm{pH}$ tanah memiliki peran penting padaekologi hewan tanah, sebab jika asam atau basa semut kemungkinan tidak dapat bertahan hidup dan berkembangbiak (Suin, 2007). Pengukuran pH sangat penting dalam meneliti fauna tanah. Organisme atau spesies ada yang toleran terhadap $\mathrm{pH}$ asam dan ada pula yang $\mathrm{pH}$ basa (Rahmawati, 2004).

Kelembaban udara pada semua stasiun berkisar dari $58 \%$ - $77 \%$ (Tabel 3). Kelembaban udara merupakan faktor penting bagi serangga untuk, tumbuh, beraktifitas dan berkembangbiak. Udara yang terlalu panas atau terlalu dingin membuat serangga enggan untuk keluar dari sarangnya. Kelembaban udara yang sesuai bagi serangga adalah 73\%-100\% (Kautsar, 2013). Secara umum semut dapat hidup pada suhu yang berlebih, namun jika terlalu tinggi dapat membahayakan hewan avertebrata ini.

Suhu tanah yang ideal untuk hidup bagi semut adalah $18{ }^{\circ} \mathrm{C}-30{ }^{\circ} \mathrm{C}$. Suhu tanah sangat menentukan kehadiran dan kepadatan organisme tanah, sebab ada hubungan antara kepadatan organisme tanah dengan suhu tanah. Tanah lembab dengan sumber makanan yang melimpah sangat mendukung kehidupan semut (Suin, 2007). Rahmawati (2004) menyatakan bahwa proses reproduksi, fisiologis dan metabolisme semut akan terganggu, jika suhu tanah yang terlampau tinggi. Fluktuasi suhu tanah sangat tergantung pada keadaan topografi, cuaca, keadaan tanah, penutupan awan, radiasi matahari, angin dan hujan. Suhu tanah hutan dipengaruhi oleh penutupan vegetasi, penutupan vegetasi yang rapat akan menghalangi masuknya sinar matahari hingga ke lantai hutan, sehingga mempengaruhi suhu permukaan tanah dan suhu udara.

\section{Kesimpulan}

Keberadaan semut di berbagai lokasi tepian sungai Musi Gandus Palembang memiliki pola fluktuasi jumlah dan jenisnya. Hal ini disebabkan oleh keanekaragaman jenis tumbuhan dan aktivitas manusia (perkebunan dan perumahan) yang ada di wilayah tersebut. Stasiun dengan jenis terbanyak, yaitu hutan dan yang paling sedikit, yaitu tepi sungai. Direkomendasikan penelitian selanjutnya pengambilan sampel dilakukan dengan waktu yang lebih lama.Waktu lebih lama kemungkinan mendapatkan jumlah dan jenis semut yang lebih banyak. Selain itu, diberikan umpan yang lebih bervariasi sehingga semut yang mendatangi umpan semakin beraneka ragam, serta metode pengambilan sampel ditambah lagi misalnya pittfall trap.

\section{Ucapan Terimakasih}

Ucapan terima kasih ditukukan kepada dosen, admin dan laboran Pendidikan Biologi FKIP Unsri. Berkat bantuan, arahan dan bimbingannya dapat terselesaikan penelitian ini.

\section{Daftar Pustaka}

Agosti D., Majer, J., Alonso, L. \& Schultz, T.R. (2000). Ants: Standard Methods for Measuring and Monitoring Biodiversity. London: Smithsonian Institution Press. ISBN: 1-56098-858-4, pp: $142-$ 143. URL: https://www.researchgate.net/publication/306359575 Ants_Standard_methods_for_measuring_and_monitori ng_biodiversity_Farsi_edition. 
Alle, W.C., Emerson, A.E., Park, T. \&Schmidt, K.P. (1967). Principles of Animal Ecology. Philadelphia: W.B. Saunders Company. ISBN 0721611206.

URL: https://www.biodiversitylibrary.org/item/31053\#p age/7/mode/1up.

Andersen, A.N. (2000). Global ecology of rainforest ants: functional groups in relation to environmental stress and disturbance. In: Agosti D, majer JD, Alonso LE, Schultz TR (Ed.). Ants: standart methods for measuring and monitoring biodiversity. Washington: Smithsonian Institution. ISBN: 1-56098-858-4, pp 25-34. URL: http://antbase.org/databases/publications_files/pu blications_20330.htm.

Bolton, B. (1994). Identification Guide to the Ant Genera of the World. Cambridge: Harvard University Press. ISBN-10: 0674442806, pp: 1232. URL https://www.researchgate.net/publication/273733 07 Book_Review_Identification_Guide to the Ant_Genera of the World.

Campbell, N.A., Reece. J.B., Urry, L.A., Cain, M.L., Wasserman, S.A., Minorsky, P.V. \& Jackson, R.B. (2008). Biology 8th edition. USA: Pearson Education, Inc.ISBN-13: 978-0-8053-6844-4, pp: 2829. URL : https://www.amazon.com/Biology-8thNeil-Campbell/dp/0805368442.

Eleanor. (2017). Book of Common Ants. Raleigh: Your wild life.ISBN-10: 022644581X, pp:1-96. URL: https://www.amazon.com/Dr-Eleanors-BookCommon-Ants/dp/022644581X.

Hashimoto, Y. (2003). Identification guide to the ant Genera of Borneo. Tools for Monitoring Soil Biodiversity in the ASEAN Region. Darwin Initiative.

URL: https://www.researchgate.net/publication/280611 $\underline{240}$

Hasriyanty, Rizali, A. \& Buchori, D. (2013). Keanekaragaman Semut dan Pola Keberadaannya pada Daerah Urban. Jurnal Entomologi Indonesia, 12 (1): 39-47. DOI: 10.5994/jei. 12.1.39.

Hölldobler, B. \& Wilson, E. O. (1990). The Ants.Cambridge: Harvard University Press. ISBN-13: 978-0674040755, pp:1-732. URL : https://www.hup.harvard.edu/catalog.php?isbn=9 780674040755 .

Kautsar, M.A. (2013). Keanekaragaman Jenis Serangga Nokturnal di Kebun Botani Kampus FKIP Universitas Sriwijaya Inderalaya dan Sumbangannya pada Pembelajaran Biologi SMA. Skripsi. Palembang: Universitas Sriwijaya.

Latumahina, F., Musyafa, M., Sumardi \& Putra, N.S. (2015). Respon Semut terhadap KerusakanAntropogenik dalam Hutan Lindung Sirimau Ambon. Jurnal Manusia dan Lingkungan, 22(2): 169-178. DOI https://doi.org/10.22146/jml.18739

Mele, P.V. \& Cuc, N.T.T. (2004). Semut sahabat petani: meningkatkan hasil buah-buahan dan menjaga kelestarian lingkungan bersama semut rangrang. Diterjemahkan oleh: Subekti Rahayu. Bogor: World Agroforestry Centre.ISBN 979-3198-15X, pp: 1-66. URL : http://www.worldagroforestry.org/publication/se mut-sahabat-petani-meningkatkan-hasil-buahbuahan-dan-menjaga-kelestarian-lingkungan.

Palys, T. (2008).Purposive sampling. In L. M. Given (Ed.) TheSage Encyclopedia of Qualitative Research Methods. (Vol.2). Sage: Los Angeles, ISBN ISBN-13: 978-1412941631, pp. 697-698. URL https://www.sfu.ca/ palys/Purposive\%20samplin g.pdf.

Philpott, S.M. \& Armbrecht, I. (2006). Biodiversity in tropical agroforests and the ecological role of ants and ant diversity in predatory function. Ecological Entomology, 31: 369-377. DOI https://doi.org/10.1111/j.13652311.2006.00793.x

Philpott, S. M., Perfecto, I., Armbrecht, I., \& Parr, L.C, (2009). Ant diversity and Function in Disturbed and Changing Habitat. https://www.researchgate.net/publication/284543 225.

Nicholas, J. (2006). Introduction toDescriptive Statistics. Sydney: Mathematics Learning CentreUniversity of Sydney, pp: 16-25. URL : https://www.sydney.edu.au/content/dam/students/ documents/mathematics-learningcentre/introduction-to-descriptive-statistics.pdf. 
Rahmawati. (2004). Studi Keanekaragaman Mesofauna Tanah di Kawasan Hutan Wisata Alam Sibolangit. USU e-USU repository: 1-17. URL: http://repository.usu.ac.id/bitstream/123456789/9 10/1/hutan-rahmawaty12.pdf.

Riyanto \& Tibrani, Mgs. M (2016). Keanekaragaman dan Kelimpahan Serangga di Sekitar DAS Sungai Musi Kota Palembang Sumatera Selatan. Dalam A. Aminuddin Bama, Prosiding SEMRATA Bidang MIPABKS-PTN Wilayah Barat. Palembang: FMIPA Universitas Sriwijaya. SSN : 2355-7192.

URLL: http://repository.unsri.ac.id/10436/.

Rizali, A., Bos, M.M., Buchori, D., Yamane, S. \& Schulze, C. H. (2008). Ants in tropical urban habitats: the myrmecofauna in a densely populated area of Bogor, West Java, Indonesia. HAYATI Biosciences, 15: 77-84.DOI: https://doi.org/10.4308/hjb.15.2.77.

Setiawan, E. (2018). KKBI kata tepian sungai. URL: https://kbbi.web.id/tepi. Diakses tanggal 20 Desember 2018.

Shidqi, B. (2015). Keanekaragaman Semut Permukiman (Hymenoptera: Formicidae di Desa Parangtritis dan Umbulharjo, Daerah Istimewa Yogyakarta. Skripsi. Yogyakarta: Perpustakaan Pusat UGM. URL:

http://etd.repository.ugm.ac.id/home/detail_penca rian/79482.

Suin, N. M. (2007). Ekologi Hewan Tanah. Bandung: Bumi Aksara.ISBN: 979-526-082-0, pp: 1-204. URL:

http://library.fip.uny.ac.id/opac/index.php?p=sho $\underline{w}$ detail\&id=6381.

Walker, K. L. (2006). Impact of the Little Fire Ant, Wasmannia auropunctata, on Native Forest Ants in Gabon. Biotropica, 38(5): 666-673. DOI https://doi.org/10.1111/j.1744-7429.2006.00198.x

Yudiyanto, Qayim, I., Munif, A., Srtiadi, D. \& Rizali, A. (2014). Keanekaragaman dan Struktur Komunitas Semut di Perkebunan Lada di Lampung. Jurnal Entomologi Indonesia. 11(2): 65-71. DOI: 10.5994/jei.11.2.65. 